\title{
Comparative Studies on Proximate and Some Mineral Composition of Selected Local Rice Varieties and Imported Rice Brands in Ghana
}

\author{
Faustina Dufie Wireko-Manu' ${ }^{1}$ \\ Cleopatra Amamoo ${ }^{2}$ (i) \\ 'Department of Food Science and Technology, Kwame Nkrumah University of Science and Technology, Kumasi, \\ Ghana \\ ${ }^{2}$ Bayport Savings and Loans PLC, 71 Osu Badu Street, Airport West, Dzorwulu, Accra, Ghana
}

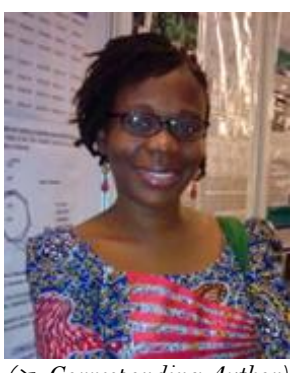

\begin{abstract}
Purpose: The objective of this study was to determine and compare the proximate and mineral ( $\mathrm{Fe}, \mathrm{Zn}, \mathrm{Mn}, \mathrm{Mg}, \mathrm{Se}$ ) composition of locally produced polished and unpolished rice and two imported rice brands. Design/methodology/approach: The proximate and mineral (Fe, $\mathrm{Zn}, \mathrm{Mn}$, $\mathrm{Mg}$, Se) composition of five local rice varieties (Maаwuwoe coop brown rice, Maawuwoe coop white rice, Shigafa brown rice, Shigafa white rice and long grain parboiled rice) and two imported brands of rice (Imported 1 and 2 ) were evaluated using standard methods after which they were compared to establish which had the higher percentage of nutrients. Findings: The percentage protein of the imported rice brands $(7.0-8.4 \%)$ were significantly higher $(\mathrm{p}<0.05)$ than those of the local rice varieties (5.69-6.89\%). The local varieties had comparable carbohydrate (74.20-79.41\%) but significantly higher fat (1.1-2.57\%) and fibre (0.64-1.95\%) contents than the imported brands (76.94-78.21\% carbohydrate, 0.49-0.88\% fat and 0.5\% fibre). Maawuwoe coop brown rice had significantly higher Fe and $\mathrm{Zn}$ contents of $96 \mathrm{mg} / 100 \mathrm{~g}$ and $2.9 \mathrm{mg} / 100 \mathrm{~g}$ respectively and Shigafa brown rice recorded the highest $\mathrm{Mn}$ content of $1.81 \mathrm{mg} / 100 \mathrm{~g}$. Imported brand 1 however had the highest $\mathrm{Mg}$ content $(96 \mathrm{mg} / 100 \mathrm{~g})$. For the local varieties, the brown had higher fibre contents $(1.95-1.65 \%)$ than that observed in the white. Originality/value: This study is meant to provide knowledge on the nutritional quality of local rice to inform consumer and subsequently enhanced patronage in Ghana.
\end{abstract}

Keywords: Local brown rice, Local white rice, Long grain, Nutrients, Quality.

Citation | Faustina Dufie Wireko-Manu; Cleopatra Amamoo (2017). Comparative Studies on Proximate and Some Mineral Composition of Selected Local Rice Varieties and Imported Rice Composition of Selected Local Rice Varieties and Imported Rice
Brands in Ghana. Agriculture and Food Sciences Research, 4(1): 1-7. History:

Received: 2 August 2016

Revised: 16 March 2017

Accepted: 13 April 2017

Published: 5 May 2017

Licensed: This work is licensed under a Creative Commons

Attribution 3.0 License $($ (c) $)$ E

Publisher: Asian Online Journal Publishing Group
Contribution/Acknowledgement: Both authors contributed to the conception and design of the study.

Funding: This study received no specific financial support.

Competing Interests: The authors declare that they have no conflict of interests.

Transparency: The authors confirm that the manuscript is an honest, accurate, and transparent account of the study was reported; that no vital features of the study have been omitted; and that any discrepancies from the study as planned have been explained.

Ethical: This study follows all ethical practices during writing.

\section{Contents}

1. Introduction

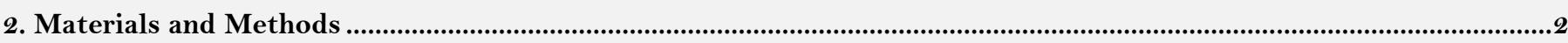

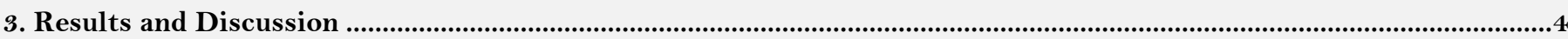

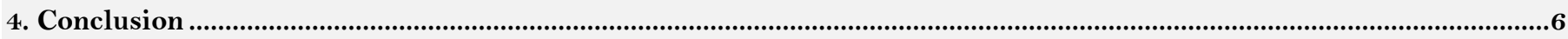

References. 


\section{Introduction}

Rice is currently the second most important food staple after maize in Ghana and its consumption keeps increasing as a result of population growth, urbanization and change in consumer habits [1]. From 2000 to 2003 the estimated consumption levels recorded commercial rice imports of approximately $61 \%$, food aid accounted for $2 \%$, and domestic rice production accounted for approximately $37 \%$ [2].

Despite the increase in production, the level of consumer demand far exceeds the supply. This has resulted in the continuous increase in the importation of the rice into the economy which is registered the highest demand deficit of 215,000 metric tonnes among selected crops in Ghana [3]. In the same year, computations by the Ghana statistical service indicated a custom value of imported rice of $\mathrm{G} H \dot{c} 108,523,136$ compared to a significantly low amount of GHф 1,186 of exported rice in Ghana.

Rice is an important food for urban dwellers and is taking over from traditional staples, mainly root crop. Rice costs are rising, according to the MOFA, and imported rice is particularly expensive. In January 2012 an 84-kg bag of locally produced paddy rice cost GHS66.20 (\$34.10), but by December it had jumped by $24 \%$ to reach GHS 81.86 (\$44.60). This is still low compared to import prices, which rose from GHS97.60 (\$50.10) for a 50-kg bag in January 2012, to GHS1 17.85 (\$60.60) in December 2012, a 21\% increase. Comparing the costs, local rice prices sat at GHSo.97 (\$0.49) per kg in December 2012, compared to GHS2.36 (\$1.20) per kg for imported rice. According to the ministry, rice imports cost the country an estimated $\$ 450 \mathrm{~m}$ annually [4].

Many urban consumers are said to prefer imported rice to local rice even though it is more expensive because it looks cleaner, more polished and more prestigious to eat and to offer to visitors. Usually quality and price of the commodity is of utmost importance when purchased. The difference in consumer preference has been attributed to several factors including poor post harvest handling, non-availability, and a general perception of poor quality physical characteristics, presence of foreign matter, nutritional quality and cooking behaviours [5].

Consumers who lived in urban area and had high standard of living, high income and education, tend to purchase rice of high quality based on their nutritional content [6]. Consumers in Ghana prefer to purchase imported rice brand rather than the local ones [7]. However local rice is said to taste better. The need to make local rice more competitive is recognized; particularly in light of nutritional composition.

Different studies have shown that the local rice varieties (Emo kokoo, Mr. More, Mui, Abodwese, Long grain, Beta, Tema, Amavi, Emo fitaa, Abibifoo mo) exhibit nutritional superiority especially in minerals such as potassium, calcium and protein contents [5]. Even though Ghanaians are aware of the locally produced rice in Ghana, most consumers are more familiar with imported rice [8]. Lack of knowledge on the nutritional quality of local rice, and the misconception that imported foods and drinks are of better quality among others might have contributed to low patronage of local rice. The situation has created low profitability. The local rice farmers are not earning enough resulting in high loss rate and unemployment in the sector [5].

The objective of this study was to determine and compare the proximate and mineral (Fe, $\mathrm{Zn}, \mathrm{Mn}, \mathrm{Mg}, \mathrm{Se}$ ) composition of locally produced white and brown rice and two imported rice brands.

\section{Materials and Methods}

\subsection{Material Source}

Five local rice varieties namely Maawuwoe coop brown rice (MCBR), Maawuwoe coop white rice (MCWR), Shigafa brown rice (SBR), Shigafa white rice (SWR) and long grain parboiled rice (LGPR) as well as two imported brands of rice (IB 1 and IB 2) were used for the study. The local varieties were purchased from Central market in Kumasi with the exception of Maawuwoe coop brown and white rice which were obtained from the CSIR-Crop Research Institute, Fumesua, Kumasi, Ghana. The two imported rice brands were obtained from a retail outlet in Kumasi based on their high consumer patronage, as revealed by a preliminary consumer survey of local and imported aromatic rice varieties sold on the market [5]. Table 1 shows the list and the sources of the selected rice varieties.

Table-1. List of selected rice varieties and their country of origin

\begin{tabular}{l|l|l}
\hline \multicolumn{2}{c}{ Table-1. List of selected rice varieties and their country of origin } \\
\hline \multirow{2}{*}{ Impouping } & Name of rice & Origin of rice \\
\hline \multirow{4}{*}{ Local varieties } & Imported brand 1 & Thailand \\
\cline { 2 - 3 } & Imported brand 2 & Thailand \\
\cline { 2 - 3 } & Maawuwoe coop brown rice & Ghana \\
\cline { 2 - 3 } & Maawuwoe coop white rice & Ghana \\
\cline { 2 - 3 } & Shigafa brown rice & Ghana \\
\cline { 2 - 3 } & Shigafa white rice & Ghana \\
\cline { 2 - 3 } & long grain parboiled rice & Ghana \\
\hline
\end{tabular}

\subsection{Sample Preparation}

The rice samples were ground with a blender into fine powder and stored in labelled polythene bags under room temperature until required for analysis.

\subsection{Chemical Analysis}

\subsubsection{Proximate Analysis}

The methods for analyses were the standard procedures of AOAC [9]. All proximate components were analyzed in duplicate and reported as mean on \% dry weight basis. 


\subsubsection{Determination of \% Moisture Content}

Two grams of each sample was weighed in a crucible and dried to constant weight at $105{ }^{\circ} \mathrm{C}$ for 6 hours in a drying oven. Crucible plus sample was cooled in a desiccator and re-weighed. The moisture content was calculated as percentage moisture lost.

\subsubsection{Determination of \% Crude Lipid and Crude Fibre Content}

Two grams of the rice samples were weighed in a porous thimble of a Soxhlet apparatus. The thimble was placed in an extraction chamber, which was suspended above a pre weighed receiving flask containing petroleum ether. The flask was heated on a heating mantle for $8 \mathrm{hr}$ to extract the crude lipid. After the extraction, the thimble was removed from the Soxhlet apparatus and the solvent distilled off. The flask containing the crude lipid was heated in the oven at $100{ }^{\circ} \mathrm{C}$ for $30 \mathrm{~min}$ to evaporate the solvent, then cooled in a desiccator, and reweighed. The difference in weight was expressed as percentage crude lipid content.

Crude fibre was estimated by acid-base digestion with $1.25 \% \mathrm{H}_{2} \mathrm{SO} 4$ (prepared by diluting $7.2 \mathrm{ml}$ of $94 \%$ conc. acid of specific gravity $1.835 \mathrm{~g} / \mathrm{ml}$ per $1000 \mathrm{ml}$ distilled water $)$ and $1.25 \% \mathrm{NaOH}(12.5 \mathrm{~g}$ per $1000 \mathrm{ml}$ distilled water) solutions. The residue after crude lipid extraction was put into a $600 \mathrm{ml}$ beaker and $200 \mathrm{ml}$ of boiling $1.25 \%$ sulphuric acid added. The contents were boiled for 30 minutes, cooled, filtered through a filter paper and the residue was washed with boiling water until washings were no longer acidic. The washed residue was returned to the digestion flask and further digested by boiling in $200 \mathrm{ml}$ of $1.25 \%$ sodium hydroxide for 30 minutes. The digest was filtered through a porous crucible to obtain the residue. This was washed with boiling water and finally with $15 \mathrm{ml}$ of $95 \%$ ethanol. The washed residue was dried in an oven at $110{ }^{\circ} \mathrm{C}$ to constant weight and cooled in a dessicator. The residue was scraped into a pre-weighed porcelain crucible, weighed, ashed at $550{ }^{\circ} \mathrm{C}$ for 30 minutes, cooled in a dessicator and reweighed. Crude fibre content was expressed as percentage loss in weight on ignition.

\subsubsection{Determination of \% Nitrogen Content and Estimation of Crude Protein \\ 2.3.1.3.1. Digestion}

Two grams of each air dried sample was weighed into $500 \mathrm{ml}$ long-necked kjeldahl flask and $10 \mathrm{ml}$ distilled water was added to moisten the sample. One spatula full of kjeldahl catalyst (mixture of 1 part selenium +10 parts $\mathrm{CUSO}_{4}+100$ parts $\mathrm{Na}_{2} \mathrm{SO}_{4}$ ) was added followed by $20 \mathrm{ml}$ conc. $\mathrm{H}_{2} \mathrm{SO}_{4}$. The solution was digested until clear and colourless. The flask was allowed to cool; the fluid decanted into a $100 \mathrm{ml}$ volumetric flask and made up to the mark with distilled water.

\subsection{Distillation}

An aliquot of $10 \mathrm{ml}$ fluid from the digested sample by means of a pipette was transferred into kjeldahl distillation flask. Ninety (90) $\mathrm{ml}$ of distilled water was added to make it up to $100 \mathrm{ml}$ in the distillation flask. Twenty (20) $\mathrm{ml}$ of $40 \%$ sodium hydroxide was added to the content of the distillation flask. Distillate was collected over $10 \mathrm{ml}$ of $4 \%$ boric acid and 3 drops of methyl red in a $200 \mathrm{ml}$ conical flask. The presence of nitrogen gave a light blue colour.

\subsection{Titration}

The collected distillate (about $100 \mathrm{ml}$ ) was titrated with $0.1 \mathrm{~N} \mathrm{HCL}$ till the blue colour changed to grey and then suddenly flashed to pink. A blank determination was carried out without a sample. Crude protein was estimated by multiplying the value obtained for percentage nitrogen content by a factor of 6.25.

\subsubsection{4. \% Ash Determination}

Ash crucibles were preheated in an oven, cooled in a desiccator and weighed. Two grams of each sample was weighed into the crucibles and then placed in a muffle furnace at $600{ }^{\circ} \mathrm{C}$ for 4 hours. Crucibles plus ashed samples were cooled in a desiccator and weighed.

\subsubsection{5. \% Carbohydrate Determination}

Carbohydrate was determined as the difference between 100 and the sum of the percentages of water, protein, total lipid (fat), and ash.

\subsubsection{Mineral Analysis}

Samples were ashed in a porcelain crucible at $550{ }^{\circ} \mathrm{C}$ in a muffle furnace for four hours, removed from the furnace and cooled. The ash was moistened with $2 \mathrm{ml}$ of distilled water and slowly and carefully the ash was dissolved in $5 \mathrm{ml}$ of $8 \mathrm{~N} \mathrm{HCl}$. The crucible was covered and placed on steam water bath for 20 minutes, cooled and transferred into $100 \mathrm{ml}$ volumetric flask by filtering using Whatman No. 42 filter paper catching the filtrate in the $100 \mathrm{ml}$ volumetric flask and made up to standard volume. The crucible was washed well with water, the washing going through the filter. The filter paper was washed several times with distilled water and made up to the $100 \mathrm{ml}$ mark and shaken vigorously to assure complete mixing. Selenium, Iron, Zinc, Magnesium, and manganese were analysed by ICP-AAS (induced coupled plasma - atomic absorption spectrometry). All determinations were carried out in duplicate and reported as mean mineral content in $\mathrm{mg} / 100 \mathrm{~g}$ dry matter (DM). Concentrations for each element were determined from previously calibrated standard curves.

\subsection{Statistical Analysis}

Data were reported as mean \pm standard deviation for at least duplicate analyses of the same extract. ANOVA was used to analyse the means of $Z$ samples and the least significant difference was used to further determine exactly where the differences occurred, at $5 \%$ significance level. 


\section{Results and Discussion}

\subsection{Proximate Composition}

Results of proximate composition for the local and imported rice types are shown in Table 2. Moisture content $(11.46-15.17 \%)$ of the varieties (both local and imported) were significantly different $(p<0.05)$. These values closely correspond to the results of $11.65 \%$ to $13.43 \%$ reported by Eshun [10] and $12 \%$ reported by Abbey, et al. [11]. Maаwuwo coop brown rice (MCBR) had higher moisture content of $15.17 \%$ which may be attributed to its drying temperature used [12]. The relatively higher moisture content of MCBR may have effect on its storage. Long grain parboiled rice (LGPR) and Shigafa white rice (SWR) had the least percentage moisture of $12.07 \%$ and $11.46 \%$ respectively which may be due to the parboiling process [12] and may have the potential to store relatively longer. The significant difference observed in the moisture content of the rice varieties may be attributed to temperature and duration of drying as well as difference in storage conditions at source.

The crude fat values obtained ranged between $0.49-2.57 \%$ with the imported brands having lower values compared to local ones even though the values are well in line with the range of 0.4 to $0.8 \%$ reported by Laureys [13]. The variety MCWR had the highest fat content of $2.57 \%$ with Import Brand 1 (IB 1 ) recording the lowest fat content of $0.49 \%$ respectively (Table 2$)$. Statistical analysis revealed a significant difference $(p<0.05)$ in the crude fat values for the rice varieties. Rice bran, being an excellent fat source, which is lost during milling contributes to the low fat content in the well-polished imported rice brands. Thus the observed difference may be attributed to the degree of milling. Milling and polishing of rice removes the outer layer of the grain where most of the fats are concentrated [14].

The values obtained for percentage ash content in this study ranged between $0.5-1.5 \%$. Maawuwoe coop white rice had the highest ash content of $1.50 \%$ followed by LGPR which had 1\% while the other rice varieties had the least ash contents of $0.5 \%$. Values obtained in this study corresponds closely with the values obtained by Ebuehi and Oyewole [15] who reported ash values of $0.53 \%$ and $0.80 \%$ for raw 'aroso' and 'ofada' rice varieties respectively in Nigeria. Kwarteng, et al. [6] also reported $0.48 \%$ to $0.6 \%$. The ash content of a food sample gives an idea of the mineral elements present in the food sample [16]. Minerals are more concentrated in the bran and thus get lost during milling and polishing when the bran is removed from the grain [17]. The ash content of $0.5 \%$ observed in the other varieties may be due to the degree of milling/polishing which is influenced by variety. As stated earlier, rice bran contains much more minerals than the actual endosperm and the tendency of rice bran to stick to the grains during milling and polishing (which is a varietal trait) influences ash content [6].

Table-2. Proximate composition of some local and imported rice types in Ghana

\begin{tabular}{l|l|l|l|l|l|l|l}
\hline \multirow{2}{*}{ Type } & Sample & Moisture (\%) & Ash (\%) & Fat (\%) & Protein (\%) & Fiber (\%) & $\begin{array}{l}\text { Carbohydrate } \\
(\%)\end{array}$ \\
\hline \multirow{2}{*}{ Local } & MCBR & $15.17 \pm 0.26^{\mathrm{bfhj}}$ & $0.5 \pm 0.00$ & $1.85 \pm 0.20^{\mathrm{bdfg}}$ & $5.69 \pm 0.00^{\mathrm{b}}$ & $1.65 \pm 0.21^{\mathrm{bd}}$ & $75.14 \pm 0.06^{\mathrm{a}}$ \\
\cline { 2 - 8 } & MCWR & $14.19 \pm 0.05^{\mathrm{bfg}}$ & $1.5 \pm 0.04$ & $2.57 \pm 0.18^{\mathrm{bdfh}}$ & $6.79 \pm 1.55^{\mathrm{b}}$ & $0.75 \pm 0.07^{\mathrm{b}}$ & $74.2 \pm 2.70^{\mathrm{adfh}}$ \\
\cline { 2 - 8 } & LGPR & $12.07 \pm 0.26^{\mathrm{adehi}}$ & $1.0 \pm 0.007$ & $1.1 \pm 0.17^{\mathrm{ae}}$ & $6.89 \pm 0.16^{\mathrm{b}}$ & $0.64 \pm 0.05^{\mathrm{a}}$ & $78.30 \pm 0.58^{\mathrm{ag}}$ \\
\cline { 2 - 8 } & SBR & $13.83 \pm 0.05^{\mathrm{bcfg}}$ & $0.5 \pm 0.00$ & $1.35 \pm 0.17^{\mathrm{bde}}$ & $6.45 \pm 0.16^{\mathrm{b}}$ & $1.95 \pm 0.07^{\mathrm{bd}}$ & $75.92 \pm 0.04^{\mathrm{ae}}$ \\
\cline { 2 - 8 } & SWR & $11.46 \pm 0.028^{\mathrm{ad}}$ & $0.5 \pm 0.00$ & $1.46 \pm 0.00^{\mathrm{bde}}$ & $6.45 \pm 0.16^{\mathrm{b}}$ & $0.72 \pm 0.07^{\mathrm{bc}}$ & $79.41 \pm 0.26^{\mathrm{bc}}$ \\
\hline \multirow{2}{*}{$\begin{array}{l}\text { Imported } \\
\text { brand }\end{array}$} & IB 1 & $12.78 \pm 0.65^{\mathrm{a}}$ & $0.5 \pm 0.00$ & $0.88 \pm 0.18^{\mathrm{a}}$ & $8.4 \pm 0.44^{\mathrm{a}}$ & $0.50 \pm 0.00^{\mathrm{a}}$ & $76.94 \pm 0.38^{\mathrm{a}}$ \\
\cline { 2 - 7 } & IB 2 & $13.30 \pm 0.18^{\mathrm{ac}}$ & $0.5 \pm 0.00$ & $0.49 \pm 0.002^{\mathrm{bc}}$ & $7.0 \pm 0.00^{\mathrm{a}}$ & $0.50 \pm 0.00^{\mathrm{a}}$ & $78.21 \pm 0.18^{\mathrm{ac}}$ \\
\hline
\end{tabular}

Note: Values are means \pm standard deviations of duplicate determinations. Values in the same column having the same superscript letters are not significantly different at $5 \%$ significant level.

Key:

$\begin{array}{lc}\text { Sample } & \text { Sample code } \\ \text { Maawuwoe coop brown rice } & \text { MCBR } \\ \text { Maawuwoe coop white rice } & \text { MCWR } \\ \text { long grain parboiled rice } & \text { LGPR } \\ \text { Shigafa brown rice SBR } & \text { SBR } \\ \text { Shigafa white rice SWR } & \text { SWR } \\ \text { Imported Brand 1 } & \text { IB 1 } \\ \text { Imported Brand } 2 & \text { IB 2 }\end{array}$

Carbohydrate values in the varieties ranged from $74.20 \%$ for MCWR to $79.41 \%$ in SWR. Virtually all the rice varieties have appreciably high carbohydrate content (Table 2 ). The variation in values for carbohydrate among the varieties was statistically significant $(\mathrm{p}<0.05)$. These values also correspond closely to that reported by Abbey, et al. [11] and Laureys [13]. Ebuehi and Oyewole [15] had 78.3\% and 81.1\% for raw 'ofada' and 'aroso' rice varieties respectively. The observed high carbohydrate content of both local and imported rice varieties affirm that rice is a carbohydrate food source. Generally, the local varieties had significantly higher crude fibre than the imported brands.

The range of values for crude fibre observed in this study was between $0.5-1.95 \%$ for the two imported rice types and Shigafa brown rice respectively. These values agree with crude fibre values of other varieties which range from $0.59 \%$ for IDSA 85 to $0.89 \%$ for Jasmine 85 and $0.86 \%$ for Sikamo and $0.87 \%$ for Nerica-2 [10]. Statistical analysis revealed a significant difference $(\mathrm{p}<0.05)$ in the crude fibre values for the rice varieties. Maawuwoe coop brown rice does not have any of its parts, including the germ, the bran, and the endosperm, removed (has not been refined) hence its high fibre content of $1.95 \%$. The high crude fibre content in Shigafa brown rice may also be due to the fact that is a whole grain which contains all three components: bran, germ, and endosperm [18]. Milling of rice during the production of polished rice generally decreases the fibre contents, hence the relatively low fibre in the imported brands [19]. The bran is particularly rich in dietary fibre and contains significant quantities of starch [20] which also contributes to the carbohydrate content of brown rice. The observed difference may be due to the fact that the imported rice brands are more polished than the local varieties. Percentage carbohydrate could also be influenced by other environmental factors under which rice is grown (soil type, crop management practices, rainfall, solar radiation, and growth temperature) [19]. 
The protein contents of the rice varieties ranged from $5.64 \%-8.40 \%$ (Table 2). The findings of this study showed that the imported rice brands had higher protein contents of $7 \%$ and $8.4 \%$ respectively. These values compare closely to those reported by Abbey, et al. [11] and Laureys [13] as 7.0\% for polished rice. Maawuwoe coop brown rice had the least protein value of $5.64 \%$ but was even higher than what was reported earlier by Kwarteng, et al. [6] a range of $5.10-5.30 \%$.

The variations observed may be due to varietal and environmental influences. [21, 22] reported that deposition of protein in rice grains depends on plethora of interrelated metabolic pathways involved in uptake of $\mathrm{N}$, Fe and $\mathrm{Zn}$ from soil, their transport to source tissues such as culms and leaves and mobilization and/or remobilization to developing grains. Each of these processes is governed by several genes and influenced by environmental factors such as soil type, drought, fertilizers application, genotype, environment interaction [23, 24].

The significant difference in percentage of crude protein between the imported varieties and the local varieties may be as a result of genotype and environmental differences [25]. Most of the protein is found in the endosperm layer with additional protein found in the bran layer which constitutes about $7-9 \%$ of the whole grain. These contributes to the percentage of crude protein in the local varieties [26].

\subsection{Mineral Composition}

The results of the mineral (iron, zinc, magnesium, manganese and selenium) analysis of the local and imported rice types are shown in Table 3. The values of iron obtained agree to those reported by Ebuehi and Oyewole [15] and Diako, et al. [5]. The SBR recorded the highest iron content of $96 \mathrm{mg} / 100 \mathrm{~g}$ and IB 1 had the lowest iron content of $11.1 \mathrm{mg} / 100 \mathrm{~g}$. Significant differences $(\mathrm{p}<0.05)$ were observed in iron contents among the local rice varieties and between the local and imported varieties.

This may be due to the fact that the brown variety is a whole grain which has its bran particularly rich in dietary minerals such as iron. The difference in iron content among the rice varieties may also be influenced by nitrogen application and soil quality [27].

The magnesium values obtained in the rice varieties ranged from $66.7 \mathrm{mg} / 100 \mathrm{~g}$ in SBR to $96 \mathrm{mg} / 100 \mathrm{~g}$ in IB 2 with a significant difference $(\mathrm{p}<0.05)$. The values of magnesium obtained for the rice varieties correspond with the $67.0 \mathrm{mg} / 100 \mathrm{~g}$ and $82.0 \mathrm{mg} / 100 \mathrm{~g}$ respectively for raw 'ofada' and raw 'aroso' rice varieties reported by Ebuehi and Oyewole [15]. The local intra varietal differences could be due to genetic factors or the mineral content of the soil on which they were grown [17]. In general, the more rice bran is removed from the grain during polishing, the more vitamins and minerals are lost [19].

The manganese values obtained from the study ranged from $1.81 \mathrm{mg} / 100 \mathrm{~g}$ in SBR to $1.09 \mathrm{mg} / 100 \mathrm{~g}$ in IB 1 . The values of manganese obtained for the rice varieties are similar to those reported by Tinsley and Emeritus [28]. Imported Brand 1 (IB 1) recorded the lowest manganese content which may be due to the fact that minerals are highest in the bran which is lost during processing [27]. The difference in the manganese contents among the rice varieties might be as a result of fertilizer application, rate of parboiling and the amounts of soil nutrients all of which affect the mineral contents of rice.

The zinc values obtained in Table 3 ranged from $1.05 \mathrm{mg} / 100 \mathrm{~g}$ in LGPR to $2.9 \mathrm{mg} / 100 \mathrm{~g}$ in MCBR. These values agreed with earlier findings by Trinidad, et al. [29] who found a range of 1.40 to $1.79 \mathrm{mg} / 100 \mathrm{~g}$ and 1.97 $\mathrm{mg} / 100 \mathrm{~g}$ reported by Tinsley and Emeritus [28]. The bran and the germ in brown rice contain many vitamins and minerals contributing to MCBR having the highest zinc content. The zinc content in the parboiled rice may be due to prior cooking which preserves some of the nutrient content, as micronutrients are transferred from the aleurone and germ into the starchy endosperm [30].

Selenium contents were $<0.1 \mathrm{mg} / 100 \mathrm{~g}$ for all the rice varieties which did not agree with the $0.15 \mathrm{mg} / 100 \mathrm{~g}$ reported by Tinsley and Emeritus [28] Soils are frequently low in available Se [31,32]. Se availability in soils depends upon soil $\mathrm{pH}$, redox potential, calcium carbonate level, cation exchange capacity, and organic carbon, iron $(\mathrm{Fe})$ and aluminium (Al) levels [33]. The low selenium contents in both the local and imported varieties may be due to the effect of non-application of selenium enriched fertilizer on the soil where the rice varieties were cultivated. Selenium content and assimilation of rice could be promoted by selenium foliar application on rice.

Table-3. Mean mineral composition of some local and imported rice types in Ghana

\begin{tabular}{|c|c|c|c|c|c|c|}
\hline \multirow[t]{2}{*}{ Type } & \multicolumn{6}{|c|}{ Minerals (mg/100g) } \\
\hline & Sample & Iron & Zinc & Magnesium & Manganese & Selenium \\
\hline \multirow[t]{5}{*}{ Local } & MCBR & $96 \pm 0.03^{\text {bdfg }}$ & $2.9 \pm 0.14^{\mathrm{bdfh}}$ & $62.4 \pm 1.40^{\text {bdfhjk }}$ & $1.16 \pm 0.01$ bdfhjk & $<0.10$ \\
\hline & MCWR & $48 \pm 0.01^{\text {bdfh }}$ & $1.94 \pm 0.01^{\mathrm{a}}$ & $76.0 \pm 0.00^{\text {bdhhjl }}$ & $1.59 \pm 0.01$ bdfhjl & $<0.10$ \\
\hline & LGPR & $73 \pm 0.01^{\text {bdf }}$ & $1.05 \pm 0.007^{\mathrm{bdfg}}$ & $72.0 \pm 1.40$ bdfhi & $1.67 \pm 0.01$ bdfhi & $<0.10$ \\
\hline & SBR & $20.7 \pm 0.01^{\text {bde }}$ & $1.72 \pm 0.03^{\text {bde }}$ & $66.72 \pm 0.00^{\mathrm{bdfg}}$ & $1.81 \pm 0.03 \mathrm{bdfg}$ & $<0.10$ \\
\hline & SWR & $11.47 \pm 0.42^{\text {be }}$ & $1.3 \pm 0.00^{\mathrm{bc}}$ & $48.0 \pm 1.40$ bde & $1.29 \pm 0.00$ bde & $<0.10$ \\
\hline \multirow{2}{*}{$\begin{array}{l}\text { Imported } \\
\text { brand }\end{array}$} & IB 1 & $89.0 \pm 0.00^{\mathrm{a}}$ & $1.91 \pm 0.00^{\mathrm{a}}$ & $96.0 \pm 1.40^{\mathrm{a}}$ & $1.09 \pm 0.00^{\mathrm{a}}$ & $<0.10$ \\
\hline & IB 2 & $11.1 \pm 0.04^{\mathrm{bc}}$ & $1.92 \pm 0.03^{\mathrm{a}}$ & $79.0 \pm 2.80 \mathrm{bc}$ & $1.47 \pm 0.03 \mathrm{bc}$ & $<0.10$ \\
\hline
\end{tabular}

Note: Values are means \pm standard deviations of duplicate determinations. Means with the same alphabet as superscript within columns are not

significantly different at $5 \%$ significant level

In general, the levels of minerals from some of the varieties like Shigafa brown rice and Maawuwoe white rice varieties are high in comparison to the other local varieties and imported brands. This may be due to genetic factors or the mineral content of the soil as well as polishing and processing [17]. The rate of fertilizer application and the native fertility of paddy fields have been shown to affect the mineral levels of rice [34].

An analysis of nutrient content of rice suggests that the nutritional component of rice is one of the most important indicators of quality; rice is predominantly a starchy food though it also contributes useful quantities of proteins and vitamins, mineral and fiber.

The chemical composition (nutrients) of rice grain varies considerably depending on factors like plant variety (breeds), environmental condition (i.e. location and season in which grown), fertilizer treatment, degree of milling, 
and condition of storage [35]. As with all natural foods, the precise nutritional composition of rice varies depends on the variety, soil conditions, environmental conditions and types of fertilizers.

\section{Conclusion}

The local rice compared well with imported rice in terms of carbohydrate (74.20-79.41\%) but had significantly higher fat (1.1-2.57\%) and fibre (0.64-1.95\%) while the imported rice had higher protein content (7.0-8.4\%). The local rice Maаwuwoe coop brown rice had significantly high Fe and $\mathrm{Zn}$ contents, $96 \mathrm{mg} / 100 \mathrm{~g}$ and $2.9 \mathrm{mg} / 100 \mathrm{~g}$ respectively; while Shigafa brown rice recorded the highest for Mn, $1.81 \mathrm{mg} / 100 \mathrm{~g}$. The imported brand 1, however had the highest $\mathrm{Mg}$ content (96 $\mathrm{mg} / \mathrm{lo0g})$.

The results show that local rice is a nutritious staple crop, containing most of the essential nutrients. Efforts to improve local rice consumption in Ghana should introduce other desirable attributes such as taste into breeding programmes to make local rice attractive to consumers. Education and advertisement of nutritional characteristics of local rice are important steps to improve the patronage of local rice in Ghana.

\section{References}

[1] MOFA, "Agriculture in Ghana: Facts and figures, statistics," Research and Information Directorate (SRID), vol. 1, 2009

[2] S. Asuming-Brempong and Y. Osei-Asare, Has imported rice crowded-out domestic rice production in Ghana? What has been the role of policy? African Association of Agricultural Economists (AAAE) Conference Proceedings, 2007.

[3] Statistics Research and Information Directorate (SRID), Agriculture in Ghana, 2006. Facts and figures report. Accra, Ghana: Ministry of Food and Agriculture, 2006a.

[4] Oxford Business Group, "Closing the gap: The rising cost of rice imports is driving change in domestic production," The Report: Ghana 2013 | Agriculture, 2014.

[5] C. Diako, E. Sakyi-Dawson, B. Bediako-Amoa, F. K. Saalia, and J. T. Manful, "Consumer perceptions, knowledge and preferences for aromatic rice types in Ghana," Nature and Science, vol. 8, pp. 12-19, 2010. View at Google Scholar

[6] E. A. Kwarteng, W. O. Ellis, I. Oduro, and J. T. Manful, "Rice grain quality: A comparison of local varieties with new varieties under study in Ghana," Food Control, vol. 14, pp. 507-514, 2002. View at Google Scholar

[7] K. Tomlins, J. Manful, P. Larwer, and L. Hammond, "Urban consumer preferences and sensory evaluation of locally produced and importedrice in West Africa," Food Quality and Preference, vol. 16, pp. 79-89, 2005. View at Google Scholar | View at Publisher

[8] A. Francis, Market organisation and consumers' perception of locally produced rice in the Ashanti region of Ghana vol. 7 . Kumasi, Ghana: Kwame Nkrumah University of Science \& Technology (KNUST), 2009.

[9] AOAC, Official methods of analysis, 15th ed. Washington: Association of Official Analytical Chemist, 1990.

[10] G. Eshun, Baseline data on the nutrient content and physicochemical properties of selected varieties of soybean, groundnut and rice for the development of nutritious, energy-dense diets, Kwame Nkrumah University of Science and Technology. Kumasi, Ghana: Department of Biochemistry and Biotechnology, Faculty of Biosciences, College of Science, 2009.

[11] T. K. Abbey, A. Alhassan, K. Ameyibor, J. W. Essiah, E. Fometu, and M. B. Wiredu, Integrated science for senior secondary schools vol. 75, 76, 451. Accra North, Ghana: Unimax Maxmillan Ltd, 2001.

[12] X. Xheng and Y. Lan, "Effects of drying temperature and moisture content on rice taste quality," Agricultural Engineering International, vol. 49, pp. 24-277, 2006. View at Google Scholar

[13] C. Laureys, "A natural choice for texture in: Rice derivatives, Sunrice research organization, P. Williams, Y. Pan and V. Poulson," p. $2,1999$.

[14] M. Frei and K. Becker, "Studies on the in vitro starch digestibility and the glycemic index of six different indigenous rice cultivars from the Philippines," Food Chemistry, vol. 83, pp. 395-402, 2003. View at Google Scholar | View at Publisher

[15] O. A. T. Ebuehi and A. C. Oyewole, "Effect of cooking and soaking on physical characteristics, nutrient composition and sensory evaluation of indigenous and foreign rice varieties in Nigeria," African Journal of Biotechnology, vol. 6, pp. 1016-1020, 2007. View at Google Scholar

[16] C. O. Edeogu, F. C. Ezeonu, A. N. C. Okaka, C. E. Ekuma, and S. O. Elom, "Proximate composition of staple food crops in Ebonyi State (South Eastern Nigeria)," International Journal of Biotechnology and Biochemistry, vol. 3, pp. 1-8, 2007. View at Google Scholar

[17] H. Rivero, J. Mario, H. Raquel, F. Lorena, V. Liliana, and D. Elena, "Concentration of As, Ca, Cd, Cr, Cu, Fe, Hg, K, Mg, Mo, Na, $\mathrm{N}, \mathrm{Pb}$ and $\mathrm{Zn}$ in uruguayan rice, determined by AAS " Atomic Spectroscopy, vol. 27, pp. 48-55, 2007. View at Google Scholar

[18] S. Liu, W. C. Willett, J. E. Manson, F. B. Hu, B. Rosner, and G. Colditz, "Relation between changes in intakes of dietary fiber and grain products and changes in weight and development of obesity among middle-aged women," American Journal of Clinical Nutrition, vol. 78, pp. 920-927, 2003. View at Google Scholar

[19] A. O. Oko and S. I. Ugwu, "The proximate and mineral compositions of five major rice varieties in Abakaliki, South-Eastern Nigeria," International Journal of Plant Physiology and Biochemistry, vol. 3, pp. 25-27, 2010. View at Google Scholar

[20] J. Barron, "Black rice bran, the next superfood? Baseline of Health Foundation. 21ST SEPT." Retrieved from https://jonbarron.org/article/black-rice-bran-next-superfood, 2010.

[21] M. A. Grusak, "Enhancing mineral content in plant food products," Journal of the American College of Nutrition, vol. 21, pp. 178-183, 2002 .

[22] A. A. Mahmoud, S. Sukumar, and H. B. Krishnan, "Interspecific rice hybrid of Oryza sativa $\times$ Oryzanivararevealsa significant increase in seed protein content," Journal of Agricultural and Food Chemistry, vol. 56, pp. 476-482, 2008.

[23] R. K. Singh, P. L. Gautam, S. Saxena, and S. Singh, Scented rice germplasm: Conservation evaluation and utilization. In: Singh, U., S., Singh, R., K., andKhush, G., S., Aromatic rices. New Delxi, Calcutta: Oxford \& IBH Publishing Co. Pvt. Ltd, 2000.

[24] G. B. Gregorio, "Progress in breeding for trace minerals in staple crops," Journal of Nutrition, vol. 132, pp. 45-47, 2002. View at Google Scholar

[25] A. O. Oko, B. E. Ubi, A. A. Efisue, and N. Dambaba, "Comparative analysis of the chemical nutrient composition of selected local and newly introduced rice varieties grown in Ebonyi State of Nigeria," International Journal of Agriculture and Forestry, vol. 2 , pp. 16-23, 2012. View at Google Scholar | View at Publisher

[26] D. J. Janow, "Oryzatein: Innovations in nutritional ingredients and food processing session 3," presented at the New Products \& Technologies, Dept. of Research and Development, Axiom Foods, Inc., 1220 Yale St., Ste. 5, Santa Monica, CA 90404 IFT Annual Meeting, July 15-20 - New Orleans, Louisiana, 2005.

[27] FAOSTAT, FAOSTAT statistical database. Rome: Food and Agriculture Organization, 2001.

[28] R. L. Tinsley and P. Emeritus, Increasing rice productivity for the kpong irrigation project. Akuse-Asutsuare, Ghana: Colorado State University ACDI/VOCA Farmer-to-Farmer Program, 2009.

[29] T. Trinidad, A. Mallillin, R. Sagum, D. Briones, R. Encabo, and B. Juliano, "Iron absorpton from brown rice/brown rice-based meal and milled rice/ milled rice-based meal," International Journal of Food Sciences and Nutrition, vol. 60, pp. 688-693, 2009. View at Google Scholar | View at Publisher

[30] G. Kennedy, B. Barbara, and N. N. Van, Nutritional contribution of rice: Impact of biotechnology and biodiversity in rice consuming countries. Thailand: International Rice Commission, Twentieth Session, Bangkok, 2002.

[31] G. H. Lyons, J. C. R. Stangoulis, and R. D. Graham, Nutrition Research Reviews, vol. 16, pp. 45- 60, 2003. View at Google Scholar | View at Publisher

[32] M. P. Rayman, Proceedings of the Nutrition Society, vol. 61, pp. 203-2 15, 2002. View at Google Scholar | View at Publisher

[33] Z. Šramková, E. Gregováb, and E. Šturdíka, "Chemical composition and nutritional quality of wheat grain," Acta Chimica Slovaca, vol. 2, pp. 115 - 138, 2009. View at Google Scholar 
[34] F. E. Nwilene, S. O. Oikeh, T. A. Agunbiade, O. Oladimeji, O. Ajayi, M. Sie, G. B. Gregorio, A. Togota, and A. D. Taura, Increasing rice production in Sub-Saharan Africa, challenges and opportunities. Africa: A Production Hand Book, 2007. [35] P. Roy, T. Ijiri, H. Okadome, D. Nei, T. Orikasa, N. Nakamura, and T. Shiina, "Effect of processing conditions on overall energy
consumption and quality of rice (Oryza Sativa L.)," Journal of Food Engineering, vol. 89, pp. 43-348, 2008. View at Google Scholar $\mid$ View at Publisher 